Besting the Workplace Bully

\section{Marianne Ryan}

Marianne Ryan is Associate University Librarian for User Services Strategies, Northwestern University.

Correspondence concerning this column should be addressed to Marianne Ryan, Associate University Librarian for User Service Strategies, Northwestern University, 1970 Campus Drive, Evanston, IL 60208; email:marianne-ryan@northwestern.edu. f you've ever encountered a workplace bully, you are not alone. Statistics show that bullying has been steadily on the rise and has taken on a variety of different faces. ${ }^{1}$ Once upon a time, the term "bully" typically conjured up the image of a playground aggressor-someone who used physical force or intimidation to victimize others. In that simpler time, retorts such as "pick on someone your own size" or "sticks and stones may break my bones but words will never hurt me" were common. However, workplace bullying shows little correlation to the physical size of the perpetrator and, among other things, it can involve words that are destructive. The havoc it wreaks can be as bad as-or worse than-what used to happen on the playground. Bullying presents a serious management challenge.

If you have had a work life, chances are you've experienced workplace bullying somewhere. Webster defines a bully as "a blustering, browbeating person; one habitually cruel to others." Fleshing out a workplace version of the definition, "Bullying is conduct that cannot be objectively justified by a reasonable code of conduct, and whose likely or actual cumulative effect is to threaten, undermine, constrain, humiliate or harm another person or their property, reputation, self-esteem, self-confidence or ability to perform." ${ }^{2}$ A definition of victimization is "prolonged exposure to interpersonal acts of a negative nature ... which make up a highly stressful situation characterized by lack of control." ${ }^{3}$ Although bullies may convince themselves their actions are justified, bullying is ultimately so corrosive to the work environment that I would add this qualifier to the mix: often, the person who sets about making the lives of others miserable does so simply because he or she can. When nothing is done to stop the abuse, it is effectively enabled. I'd wager that most libraries have at least one such perpetrator, though some environments are far worse than others.

Experts have noted that today's bullying "is more complex, more lethal, and considerably different in many ways from bullying in the past" and that it falls into distinct types of behavior: physical, emotional (including verbal abuse and sexual harassment), and cyber. ${ }^{4}$ Any or all of these can undermine constructive workplace dynamics.

\section{PHYSICAL ABUSE}

In most of our organizations, even dysfunctional ones, bullying tends not to be reduced to acts of brute force. But that doesn't mean there isn't an aspect of physical threat. A bully's unpleasant presence may be enough to make others feel 


\section{MANAGEMENT}

uncomfortable or vulnerable. The bully may violate another's privacy, for example by going into her office space uninvited or cornering him in the stacks or in a conference room. Physical effects can be the aftermath, rather than the initial impact, of the negative behavior. For those being targeted, bullying of any kind can cause illness, anxiety, or other stress disorders that lead to lost work days or reduced productivity. The climate created by the inherent unkindness and lack of civility in verbal bullying also can have palpable negative impacts. If you dread going to work because you have to interact with "that" coworker, feel uncomfortable or threatened when "that" someone is around, or avoid certain meetings or engagement opportunities to steer clear of "that" individual, you're probably in the orbit of a bully and may be experiencing the physical effects.

\section{EMOTIONAL ANTAGONISM}

Many who study the behavior of bullies note that emotional antagonism is the broadest category of bullying and that it can include all of the others, since any form of bullying may cause mental distress. ${ }^{5}$ This is especially true when it comes to sexual harassment, a major area of concern in its own right that includes not only inappropriate physical contact, but also ridiculing another's appearance, subjecting others to explicitly graphic language, or demonstrating intolerance for another's sexual orientation. But some experts define emotional bullying more specifically as either non-verbal or psychological abuse. Non-verbal emotional mistreatment may be characterized by but not limited to eye rolling, staring, or laughing at someone else. Even a person's body language can convey that he or she has little use for another. Psychological emotional bullying "comes in the form of indirect abuse such as exclusion, isolation, rejection, turning your back on someone who is trying to talk with you, shunning, ostracizing, and ignoring. It can be subtle or overt." ${ }^{16}$ Projecting is another technique frequently used by bullies, as is making up their own rules. These disrespectful practices are especially damaging as they can undermine an individual's sense of professional or even personal worth. As much, they can significantly affect victims' own communication patterns, marginalizing or silencing them. ${ }^{7}$

\section{CYBER BULLYING}

Cyber bullying has been defined as harassment through "email, instant messaging (IM), in a chat room, on a Web site, or through digital messages or images sent to a cell

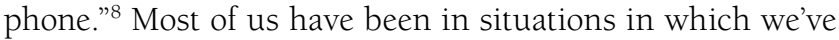
dreaded receiving electronic communication from others for one reason or another-not necessarily because they're bullies. But communiques from a bully can be particularly unpleasant. In my experience, the worst workplace bully I've known was a lateral colleague prone to sending email replete with underlined, bolded, italicized, and highlighted text-so much as to say the recipients weren't smart enough to understand what the important takeaways might be without the formatting emphasis. Another consistently employed device was to change the subject line in the second round of any given correspondence, thereby making it impossible to search easily for the entire thread. My boss would complain about the disorganized mess that resulted, indicating frustration and irritation but never acknowledging that a particular individual was almost always the source of the problem.

Another way bullies can manipulate written communication is to re-engineer routine email flow, intentionally excluding the full diversity of viewpoints expressed earlier in a conversation. Bullies love to control information. They may stop weighing in on a thread in order to start a new one. Or they may eliminate some of the addressees originally included in the message, which can get overlooked as the discussion unfolds. As often, bullies may refuse to commit things to writing at all, preferring instead to "work the shadows" by talking one-on-one with a number of individuals. This prevents anyone from pinning down the bully on just what he or she may have said to others-frequently something different to each person.

An especially problematic aspect of cyber bullying is that it is not limited to the workplace. Given that technology has made connectivity ubiquitous, this form of abuse has the potential to plague its victims 24/7/365. It never goes away.

\section{WHAT MAKES A BULLY?}

Think back to high school, and you can probably recall a bully or two. If your school's bullies were like mine, they usually weren't the good students, the cheerleaders, or the athletes. More often than not, bullies were those who got poor grades, sometimes came from troubled homes, and generally had difficulty fitting in. In an effort to compensate for their insecurities and the shortcomings in their respective situations, they attempted to assert force and inflict pain of one kind or another on peers. They would seek out allies in those who were weak and unsure of themselves. I would suggest that classic workplace bullies are not much different. Though frequently clever, they tend to be outliers-similarly insecure and unhappy, often without close family or many friends. To undermine those they feel threatened by, they prey upon the weak, whom they enlist to be their allies, in exchange for looking out for them. In so doing, bullies help elevate the incompetent to positions of authority, weakening the larger organization. Together, they create a hostile work environment, driven by their jealousy and desire for power and control.

Sad to say, the title of this column is perhaps misleading. Actually besting a bully is a tall order-much easier said than done. A recent survey indicates that "workplace bullying is rampant due to a breakdown in four levels of accountability: personal (the victim), peer (witnesses to the behavior), 
supervisory (team leaders), and formal discipline (HR)." It really takes a village, with many of those who have been victimized banding together to bring a well-formed complaint forward, enlisting the support of supervisors in the chain of command, and being able to rely on a strong HR presence in the library, as well as in the institution as a whole. Clearly, if that kind of strong and healthy infrastructure existed in a given workplace, it wouldn't be fertile ground for bullying to start with. Only half of the survey respondents indicated that their organizations had a policy for dealing with these "internal terrorists." ${ }^{10}$ For whatever reason, HR staff often feel powerless when it comes to confronting workplace bullies. A colleague at a library I once worked at shared that when she tried to enlist her own personnel officer's help handling a workplace bully, she was told, "Leave it alone. You can't win." With such a lack of support, bullying will never be reduced.

It should be noted that many institutions offer an alternative when the regular management and HR processes may have failed. Ombudspersons are appointed and empowered, usually at a level above library administration, to meet in confidence with concerned employees, advise them of their rights, and engage on a variety of levels, including a simple conversation with the appropriate manager. This can be a lifesaver for an employee who feels truly isolated. As managers, learning that a complaint has arisen inside one's organization can be a shock and may, in itself, feel threatening. But there is a better way to look at it. Assuming the manager involved is not also the bully, these extra-library processes circumvent the choke points a bully may have engineered between a manager and critical information that manager needs to know about the health of the workplace.

The potential complainant, of course, needs to weigh the pros and cons of such a step, but where the isolation is real, these outlets are there for a reason. In most public institutions and many private ones - and by law in the Federal government-whistleblowers have legal protection once a complaint is initiated. It would be naive to think that a complaint will have no impact on workplace perceptions, at least in the short run. Bullies play on those fears. It is important to find an uninvolved third party, such as a counselor or a friend, to serve as a sounding board in deciding what to do. The main thing is to reduce the isolation, then engage in the process with perspective and integrity.

Advice columns and self-help guides remind us that, given how much time we spend at work, life is too short not to enjoy it. But that's difficult to do when a bully is around. If you have never encountered a workplace bully, you are a rare-and lucky-individual. I hope your good fortune continues. Either way, please consider what you can do to help others in your library to best workplace bullies and stop their unjustifiable behavior. Bullying is the pathology of those who take pleasure in orchestrating "gotcha" moments and thrive on hurting others. It's everyone's responsibility to stand up to them. We may not succeed every time, but at the very least we send an important message. In the silent world of unchallenged bullying, those messages will whisper to bullies and victims alike that the winds of change are coming.

\section{References and Notes}

1. The incidence of workplace bullying has been increasing since the turn of this century. Some recent data suggest that upwards of 90 percent of those surveyed have experienced some aspect of it. See, for example, Jane Kasperkevic, "The 'Silent Epidemic': Workplace Bullying Is On the Rise, Research Shows," The Guardian, June 26, 2014, www.theguardian.com/money/us-money -blog/2014/jun/26/workplace-bullying-rise-research-shows; Anne-Marie Quigg, The Handbook of Dealing with Workplace Bullying (Oxford: Routledge, 2016); US Workplace Bullying Survey, February 2014, www.workplacebullying.org/wbiresearch/wbi -2014-us-survey.

2. "What Is Workplace Bullying?" accessed March 12, 2016, www .bullyonline.org.

3. Kimberly A. Parker, "The Workplace Bully: The Ultimate Silencer," Journal of Organizational Culture, Communications and Conflict 18, no. 1 (2014): 170.

4. SuEllen Fried and Blanche E. Sosland, Banishing Bullying Behavior: Transforming the Culture of Pain, Rage, and Revenge (Lanham, MD: Rowman and Littlefield, 2009), 35.

5. See, for example, Jaime Lester, Workplace Bullying in Higher Education (New York: Routledge, 2013); Linda Mata, Understanding Workplace Bullying (Bloomington, IN: AuthorHouse, 2010); Ray Williams, "The Silent Epidemic: Workplace Bullying," Psychology Today (May 3, 2011) https://www.psychologytoday.com/blog/ wired-success/201105/the-silent-epidemic-workplace-bullying.

6. Fried and Sosland, Banishing Bullying Behavior, 40.

7. Parker, "The Workplace Bully," 175.

8. Robin M. Kowalski, Susan P. Limber, and Patricia W. Agatston, Cyber Bullying: The New Moral Frontier (Oxford: Blackwell, 2008), 1.

9. Joseph Grenny and David Maxfield, "Does Bullying Provide Job Security?" Vital Smarts, June 25, 2014, https://www.vitalsmarts .com/press/2014/06/does-bullying-provide-job-security-youll -be-infuriated-by-the-answer/.

10. Bertice Berry, as cited in Scotty Ballard, "How to Handle a Workplace Bully," Jet 106, no. 4 (2004): 16. 